\title{
DESAIN ENTERPRISE RISK MANAGEMENT PADA PERGURUAN TINGGI DI STIE MUHAMMADIYAH JAKARTA
}

\author{
Lela Nurlaela Wati ${ }^{1}$, Ramdany $^{2}$, Abdul Mukti Soma ${ }^{3}$ \\ ${ }^{1,2,3}$ STIE Muhammadiyah Jakarta. Lela_nwm@yahoo.com
}

\begin{abstract}
ABSTRAK
Tujuan dari penulisan ini adalah untuk menganalisis penerapan manajemen risiko pada perguruan tinggi di Sekolah Tinggi Ilmu Ekonomi Muhammadiyah Jakarta. Metode penelitian menggunakan desain penelitian eksploratif, karena tujuan penelitian ini adalah untuk memahami permasalahan manajemen risiko pada STIE Muhammadiyah Jakarta. Data diperoleh dengan melakukan wawancara dan barinstorming dengan ketua program studi, kepala bagian, dan kepala Lembaga STIE Muhammadiyah Jakarta, juga dengan menggunakan data sekunder yaitu jumlah mahasiswa, jumlah, dosen, dan data lainnya. Tahapan analisis dilakukan melalui identifikasi risiko, penilaian dan evaluasi risiko, perencanaan mitigasi risiko dan analisis serta interpretasi data. Berdasarkan hasil identifikasi risiko, terdapat 5 risiko inherent yang bisa berdampak signifikan terhadap sustainability STIE MJ. Berdasarkan risk profile dari kelima identifikasi risiko, risiko 1 berdampak kualitatif terhadap penurunan peringkat akreditasi, risiko kedua dan ketiga berdampak terhadap tidak tercapainya sasaran kinerja, risiko keempat dan kelima dapat berdampak terhadap penurunan klasterisasi Nasional Perguruan Tinggi. Dampak kuantitatif risiko 1-3 berdampak terhadap kerugian institusi, risiko no. 4 dan 5 berdampak terhadap rendahnya penyerapan anggaran (cost center). Beberapa risiko memerlukan penangan dalam waktu yang tidak singkat seperti risiko 4 dapat mengakibatkan risiko residual tidak sesuai dengan target risiko yang diharapkan (risk appetite), sehingga diperlukan penanganan risiko secara berkelanjutan. Penelitian ini memiliki keterbatasan yaitu identifikasi risiko tidak dilakukan secara mendalam pada semua unit kerja. Penelitian mendatang diharapkan agar identifikasi risiko dilakukan pada semua unit kerja di Perguruan Tinggi, sehingga risiko yang ada dapat segera dimitigasi dan dilakukan perbaikan segera.
\end{abstract}

Kata Kunci: Enterprise Risk Management, Perguruan Tinggi

\section{ABSTRACT}

The purpose of this paper is to analyze the application of risk management in STIE Muhammadiyah Jakarta. The research method uses an exploratory research design, because the purpose of this research is to understand the problem of risk management at STIE Muhammadiyah Jakarta. The data were obtained by conducting interviews and barinstorming with the head of the study program, the head of the department, and the head of the STIE Muhammadiyah Jakarta Institute, also by using secondary data, namely the number of students, number, lecturers, and other data.. The analysis stages are carried out through risk identification, risk assessment and evaluation, risk mitigation planning and data analysis and interpretation. Based on the results of risk identification, there are 5 inherent risks that can have a significant impact on the sustainability of STIE MJ. Based on the risk profile of the five risk identifications, risk 1 has a qualitative impact on the decline in accreditation ratings, the second and third risks have an impact on not achieving performance targets, the fourth and fifth risks can have an impact on decreasing the National clustering of Higher Education. The quantitative impact of risk 1-3 has an impact on institutional losses, risk no. 4 and 5 have an impact on the low absorption of 
the budget (cost center). Some risks require handling in a short time such as risk 4 which can result in residual risk not in accordance with the expected risk target (risk appetite), so that risk management is needed on an ongoing basis. This study has limitations, namely risk identification is not carried out in depth in all work units. Future research is expected that risk identification is carried out in all work units in Higher Education, so that existing risks can be immediately mitigated and immediately corrected.

Keywords: Enterprise Risk Management, University

Naskah diterima : 29-11-2021, Naskah dipublikasikan : 30-11-2021

\section{PENDAHULUAN}

Risiko berhubungan dengan ketidakpastian, hal ini terjadi karena kurang atau tidak tersedianya cukup informasi tentang apa yang akan terjadi. Sesuatu yang tidak pasti (uncertain) dapat berakibat menguntungkan atau merugikan. Menurut Wideman dalam Mamduh (2012), ketidak pastian yang menimbulkan kemungkinan menguntungkan dikenal dengan istilah peluang (Opportunity), sedangkan ketidak pastian yang menimbulkan akibat yang merugikan dikenal dengan istilah risiko (Risk).

Secara umum, risiko akan bertambah jika kemungkinan atau akibatnya bertambah. Kedua-duanya harus dipertimbangkan dalam manajemen risiko. Risiko dalam setiap kejadian adalah fungsi dari kemungkinan (likelihood) dan akibat (impact). Untuk dapat menanggulangi semua risiko yang mungkin terjadi, diperlukan sebuah proses yang dinamakan sebagai manajemen risiko. Manajemen risiko merupakan suatu proses dalam mengidentifikasi risiko, penilaian risiko dan pengambilan langkah-langkah untuk mengurangi risiko sehingga risiko tersebut berada pada tingkat yang dapat diterima.

Banyaknya ketidakpastian yang dihadapi berbagai institusi perguruan tinggi saat ini, menimbulkan kesadaran pentingya untuk mengelola risiko yang akan timbul sehingga risiko tersebut dapat dimitigasi secara cepat dan tepat serta tidak menimbulkan kerugian besar terhadap institusi. Begitu juga dengan STIE Muhammadiyah Jakarta yang saat ini sedang berkembang memerlukan kerangka manajemen risiko untuk mendukung tujuan dan sasaran baik jangka pendek, menengah maupun jangka Panjang.

STIE Muhammadiyah Jakarta merupakan hasil pengembangan dari Akademi Akuntansi Muhammadiyah (AAM) Jakarta yang pada awalnya merupakan jurusan Akuntansi pada Akademi Keuangan Perbankan Muhammadiyah (AKPM) Jakarta, yang memiliki 4 program studi yang sudah berjalan yaitu S1 Akuntansi, S1 Manajemen dan D3 Akuntansi, dan Program Studi Magister Manajemen (http://stiemj.ac.id).

Tujuan dari kerangka manajemen risiko adalah untuk menyediakan proses formal yang diperlukan organisasi untuk membantu institusi dalam aspek: 1) mendorong pemahaman pada pimpinan unit kerja beserta seluruh staf mengenai implikasi dari keterpaparan unit kerja pada risiko, opportunities dan manajemen risiko dalam menjalankan tupoksi nya sehari-hari maupun dalam menjalankan kegiatan perencanaan strategis dan operasional. 2) mengembangkan dan menerapkan prosedur untuk memastikan bahwa risiko diidentifikasi, dinilai tingkat kerentanannya, dan memastikan bahwa langkah-langkah yang tepat diimplementasikan dan 3) mendefinisikan dan mendokumentasikan tanggungjawab dan proses yang harus dijalankan.

Penelitian mengenai penerapan enterprise risk management pada perguruan tinggi masih belum banyak dilakukan, khususnya pada Perguruan Tinggi Swasta. Mukhlis dan Supriyadi (2018) melakukan penelitian mengenai desain manajemen risiko pada Perguruan Tinggi Negeri berbadan Hukum (PTN BH) dengan study kasus pada Universitas Gadjah Mada, dengan 
menggunakan Teknik wawancara dan dokumentasi serta analisis interactive model, hasil penelitian menunjukkan bahwa manajemen risiko telah berjalan baik di UGM. Berbeda dengan hasil penelitian Mukhlis dan Supriyadi (2018), Septiawan dan Sujana (2020) menghasilkan penelitia dimana STIKIM belum menerapkan Sistem Manajemen Risiko yang disyaratkan oleh BAN-PT, dimana STIKIM tidak memiliki organ struktur yang melaksanakan manajemn risiko.

Berdasarkan uraian di atas, penulis dapat merumuskan permasalahan yaitu: Bagaimana penerapan Enterprise Risk Management pada Perguruan Tinggi dapat meminimalkan risiko yang terjadi. Tujuan penulisan artikel ini adalah untuk mengidentifikasi risiko, melakukan penilaian risiko, menganalisis risiko dan melakukan mitigasi risiko untuk mengurangi dampak atas risiko yang dihadapi oleh STIE Muhammadiyah Jakarta terutama risiko tidak tercapainya sasaran kinerja STIE Muhammadiyah Jakarta, risiko reputasi terkait pemeringkatan klasterisasi Nasionl Perguruan Tinggi, risiko Operasional dan risiko Hazard pada saat kondisi pandemic Covid-19.

\section{KAJIAN LITERATUR}

Risiko didefinisikan sebagai peristiwa yang dapat memiliki dampak pada upaya pencapaian tujuan organisasi. Risiko dapat muncul dari faktor eksternal (seperti perubahan peraturan pemerintah, perubahan karakteristik demografi mahasiswa, dan krisis ekonomi) maupun faktor internal (seperti pembukaan program studi baru, tantangan dalam penyediaan infrastruktur, penyediaan sumberdaya manusia yang memadai, dan lain-lain).

Enterprise Risk Management (Manajemen Risiko Perusahaan) adalah suatu budaya, kemampuan, dan praktik yang ada dalam Institusi, yang terintegrasi dengan penetapan strategi dan kinerjanya, yang diandalkan Institusi untuk mengelola risiko dalam upaya menciptakan, mempertahankan, dan mewujudkan nilai-nilai Institusi (ISO 31000: 2018).

Adapun tujuan penerapan ERM menurut ISO 31000: 2018 adalah:

1. Meningkatkan kemungkinan pencapaian tujuan dan peningkatan kinerja

2. Mendorong manajemen yang proaktif

3. Memberikan dasar yang kuat dalam pengambilan keputusan dan perencanaan

4. Meningkatkan efektivitas alokasi dan efisiensi penggunaan sumber daya organisasi

5. Meningkatkan kepatuhan kepada ketentuan

6. Meningkatkan kepercayaan para pemangku kepentingan

Dengan mengimplementasikan ERM maka akan banyak manfaat yang diperoleh bagi suatu Institusi khususnya dalam mewujudkan pencapaian targetnya. Manfaat Bagi Institusi:

1. Avoid Surprises dengan risk management, maka potensial risiko sudah teridentifikasi dan dikelola sebelum menjadi hal yang serius/berdampak besar.

2. Better Governance- terdapat pembagian peran dan tanggung jawab yang jelas, metode komunikasi dan pelaporan yang lancar, serta mekanisme eskalasi permsalahan.

3. Better Decision Making- membantu proses pengambilan keputusan, karena sudah memperhitungkan dampak suatu potensi kejadian atas keputusan yang akan diambil.

4. Efficiencies, fungsi pengelolaan risiko di institusi lebih efektif, mudah koordinasi risiko, dan mengurangi overlap atau adanya gap dalam pengelolaan risiko

Enterprise Risk Management yang mengacu pada standar Internasional ISO 31000 Tahun 2018, seperti ditunjukkan pada gambar berikut: 


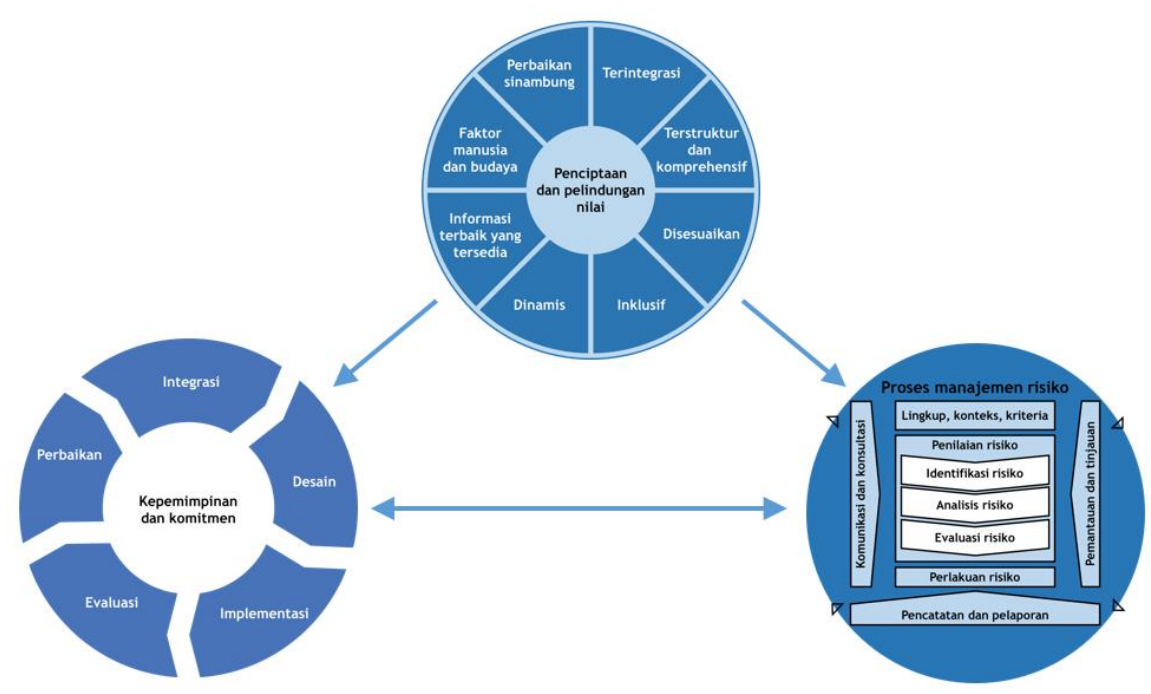

Gambar 1. Kerangka Manajemen Risiko

Sumber: ISO 31000 (2018)

ISO 31000 merupakan panduan penerapan risiko yang terdiri atas tiga elemen: prinsip (principle), kerangka kerja (framework), dan proses (process). Prinsip manajemen risiko adalah dasar praktik atau filosofi manajemen risiko. Kerangka kerja adalah pengaturan sistem manajemen risiko secara terstruktur dan sistematis di seluruh organisasi. Proses adalah aktivitas pengelolaan risiko yang berurutan dan saling terkait.

ISO 31000:2018 menekankan tujuan manajemen risiko, yaitu menciptakan dan melindungi nilai. Tujuan itu diwujudkan dengan (1) meningkatkan kinerja, (2) mendorong inovasi, dan (3) mendukung pencapaian sasaran. Manajemen risiko adalah bagian dari tata kelola (governance) dan harus terintegrasi di dalam proses organisasi. Penerapan manajemen risiko memerlukan kepemimpinan dan komitmen dari manajemen puncak, serta keterlibatan aktif dari semua anggota organisasi.

Proses Manajemen Risiko:

\section{A. Komunikasi}

Komunikasi dan konsultasi dengan seluruh unsur organisasi untuk memastikan pemahaman tentang proses manajemen risiko dan hasilnya dilakukan oleh Sekretaris Institusi. Beberapa langkah dilakukan Sekretaris institusi di antaranya adalah memfasilitasi operational review terhadap risk registers, mengkoordinasikan risk assessment, dan memastikan adanya compliance terhadap risk management framework.

\section{B. Establish context}

Manajemen risiko dilakukan dalam upaya pencapaian tujuan dan sasaran institusi. Oleh karena itu, manajemen risiko harus ditempatkan dalam konteks strategik maupun operasional. Identifikasi risiko strategik melibatkan hubungan antara institusi dengan lingkungan eksternal. Beberapa isu penting yang harus dipertimbangkan dalam mengevaluasi strategic content, di antaranya adalah peluang dan ancaman yang berhubungan dengan lingkungan lokal, regional, global, sosial, politik, kultural, kebijakan dan kompetisi, serta kekuatan dan kelemahan institusi dalam rangka mencapai tujuan korporat 
Berkaitan dengan operational context, identifikasi risiko melibatkan pemahaman terhadap kemampuan organisasi, tujuan, sasaran, kekuatan dan kelemahan dengan mempertimbangkan aspek:

- struktur organisasi dan budaya organisasi

- geografi dan demografi

- keberadaan hambatan operasional

- tujuan dan KPIs

- isu terkait dengan manajamen perubahan atau audit reviews

- kewajiban regulasi dan hambatan regulasi

- $\quad$ sistem manajemen yang dijalankan institusi

\section{Identifikasi Risiko}

Identifikasi risiko merupakan langkah kritikal, baik dalam konteks strategik maupun operasional. Risiko dapat diidentifikasi melalui beberapa langkah berikut:

- focus group discussion (brainstorming approaches, SWOT analysis techniques, dan project categories)

- workshops,

- pengalaman organisasi lain, dan

- interview dengan pihak terkait.

\section{Kategori dan Kriteria Probabilitas Risiko} Tahun 2018

Berikut ini adalah kategori risiko dan kriteria profitabilitas risiko berdasarkan ISO 31000

Tabel 1. Kategori Risiko

\begin{tabular}{ll}
\hline \multicolumn{1}{c}{ Kategori } & \multicolumn{1}{c}{ Sub Kategori } \\
\hline \multirow{2}{*}{ Strategy and Planning } & 1. Corporate Responsibility \& Sustainability (CR\&S) \\
& 2. External Factors, \\
& 3. Planning, Project, dan Strategy \\
& 1. Accounting \\
Financial Risk & 2. Credit, Liquidity \& Finance Intelligence \\
& 3. Financial Market \\
& 4. Planning \& Budgeting \\
& 1. Corporate Assets \\
& 2. Human Resources \\
& 3. Information Technology \\
4. External Events \\
Infrastructure Risk & 6. Legal \\
& 7. Process Management \\
& 8. Sales, Marketing and Communications \\
& 1. Health, Safety, \& Environment \\
& 2. Force Majeur \\
Hazard Risk & 3. Natural Disaster
\end{tabular}


JURNAL AKUNTANSI, Vol. 10, No. 2, November (2021)

Tabel 2. Kriteria Profitabilitas Risiko

\begin{tabular}{|c|c|c|c|c|}
\hline Index & Probabilitas & Deskripsi & Presentase $(\%)$ & $\begin{array}{l}\text { Persentas } \\
\text { e }\end{array}$ \\
\hline 5 & Sangat Besar & $\begin{array}{l}\text { Sangat mungkin pasti terjadi / } \\
\text { sering }\end{array}$ & $>80 \%$ & $90.00 \%$ \\
\hline 4 & Besar & Kemungkinan besar terjadi & $60<\mathrm{p} \leq 80 \%$ & $70.00 \%$ \\
\hline 3 & Sedang & $\begin{array}{c}\text { Sama kemungkinannya terjadi \& } \\
\text { tidak terjadi }\end{array}$ & $40<\mathrm{p} \leq 60 \%$ & $50.00 \%$ \\
\hline 2 & Kecil & Kemungkinan kecil terjadi & $10<\mathrm{p} \leq 40 \%$ & $25.00 \%$ \\
\hline 1 & Sangat Kecil & $\begin{array}{l}\text { Cenderung tidak mungkin } \\
\text { terjadi }\end{array}$ & $\leq 10 \%$ & $5.00 \%$ \\
\hline
\end{tabular}

\section{METODE PENELITIAN}

Desain penelitian yang digunakan pada penelitian ini adalah penelitian eksploratif. Desain riset eksploratif bertujuan untuk mendapatkan pemahaman serta gambaran mengenai masalah dalam penelitian.

Desain penelitian eksploratif digunakan karena tujuan peneliti adalah untuk memahami permasalahan manajemen risiko pada STIE Muhammadiyah Jakarta. Menurut Sauders dkk (2012). Ketika melakukan penelitian eksploratif, peneliti harus bersedia mengubah arahnya sebagai akibat dari pengungkapan data dan wawasan baru.

Sumber data yang digunakan adalah data primer dan data sekunder. Data primer dilakukan dengan wawancara dan barinstorming dengan ketua program studi, kepala bagian, kepala Lembaga serta pimpinan STIE Muhammadiyah Jakarta. Data yang dibutuhkan meliputi identifikasi serta penilaian risiko yang ada di STIE Muhammadiyah Jakarta. Data sekunder dalam penelitian ini adalah data penunjang berupa informasi terkait identifikasi risiko yang ada, jumlah dosen, jumlah mahasiswa, struktur organisasi dan data terkait lainnya.

Tahapan yang dilakukan dalam menganalisis penerapan enterprise risk management $\mathrm{di}$ STIE Muhammadiyah Jakarta adalah:

1. Identifikasi Permasalahan dan Analisis Situasi

2. Identifikasi Risiko

3. Penilaian dan Evaluasi Risiko

4. Perencanaan Mitigasi Risiko

5. Analisis dan Interpretasi data

6. Penarikan kesimpulan dari manajemen risiko 


\section{HASIL DAN PEMBAHASAN}

Proses manajemen risiko yang digunakan di STIE Muhammadiyah Jakarta mengacu pada standar internasional ISO 31000 Tahun 2018, yaitu:

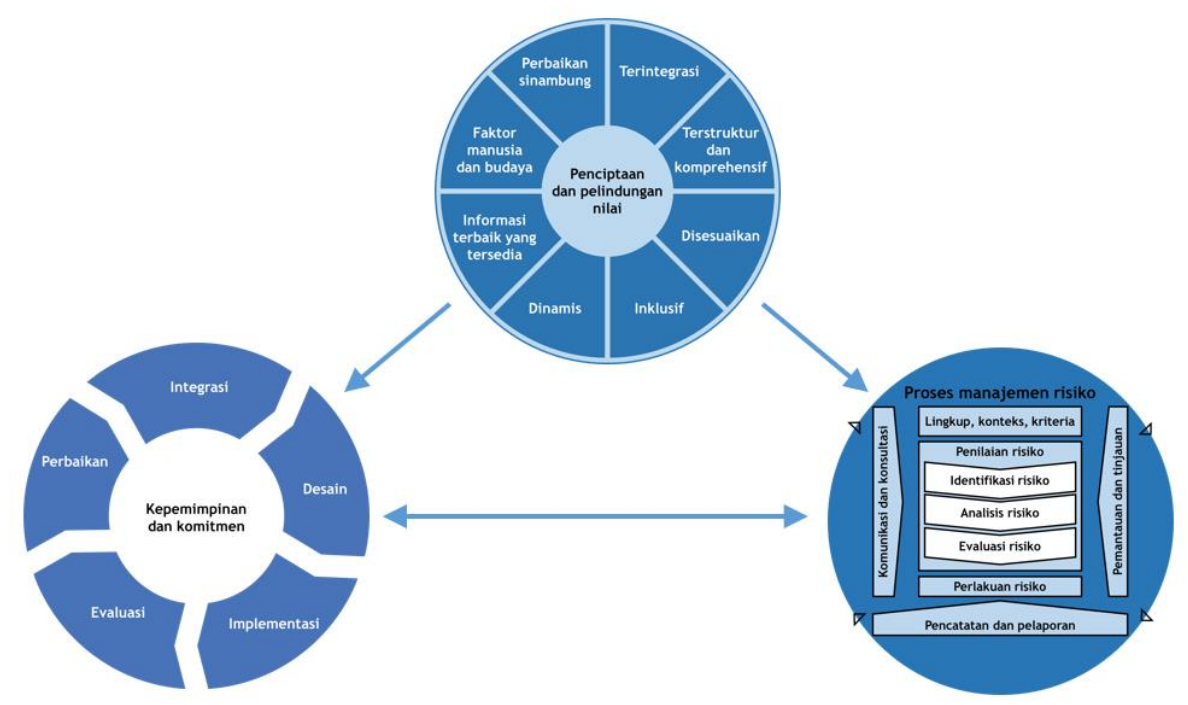

Gambar 2. Proses manajemen risiko

Sumber: ISO 31000 (2018)

\section{Batasan Kajian Manajemen Risiko}

Kajian risiko fokus pada kegiatan-kegiatan utama institusi yang merupakan bagian dari target capaian kinerja STIE Muhammadiyah Jakarta.

Sumber informasi/data:
a. Rencana Kerja STIE Muhammadiyah Jakarta TA 2020/2021
b. Kontrak Kinerja STIE Muhammadiyah Jakarta dengan Majlis Dikti PP Muh.
c. Standar Mutu STIE Muhammadiyah Jakarta Tahun 2020
d. Brainstorming

\section{Identifikasi Risiko}

Tahap selanjutnya adalah melakukan identifikasi risiko yang mengacu pada hasil hasil wawancara dengan para kaprodi, ketua Lembaga, kepala bagian dan brainstorming serta dengan menganalisis data rencana kerja, kontrak kinerja STIE Muhammadiyah Jakarta dengan Majlis Dikti Litbang PP Muhammadiyah. Dari hasil tersebut didapatkan risiko yang berpotensi menyebabkan kegagalan dipengaruhi oleh dosen, mahasiswa, kurikulum, serta lingkungan akademik yang ada pada STIE MJ. Identifikasi risiko yang berpotensi bisa menyebabkan keberlangsungan institusi STIE MJ dapat dijelaskan pada table 1 berikut ini: 
Tabel 3. Identifikasi Risiko

\section{IDENTIFIKASI RISIKO}

\begin{tabular}{ccc}
\hline NO & $\begin{array}{c}\text { KEJADIAN } \\
\text { RISIKO }\end{array}$ & AKAR PENYEBAB \\
INDIKATOR RISIKO
\end{tabular}

1. Tidak tercapainya target akreditasi Program Studi minimal B
1. Adanya penurunan jumlah mahasiswa

2. Rendahnya kolaborasi dosen dan mahasiswa dalam pelaksanaan penelitian dan publikasi ilmiah

3. Rendahnya kolaborasi dosen dan mahasiswa dalam pelaksanaan pengabdian masyarakat

4. Implementasi kerjasama dengan dunia industri/usaha kurang optimal

5. Kurang optimalnya implementasi kerjasama dengan perguruan tinggi lain baik di dalam negeri maupun luar negeri.

2 Tidak tercapainya target penerimaan mahasiswa baru TA 2021/2022

3 Jumlah Dosen berpendidikan $\mathrm{S3}$ dan Lektor Kepala dibawah $\mathbf{5 0 \%}$
1. Pandemik Covid - 19.

2. Semakin banyaknya perguruan tinggi yang melakukan Program Studi di Luar Kampus Utama (PSDKU) akibat Permendikbud Tahun 2020.

3. Kampus Negeri membuka prodi seluas-luasnya

4. Kampus swasta memberikan diskon besar besaran

1. Motivasi dosen melanjutkan study S3 rendah karena sibuk mengajar dan bekerja.

2. Beberapa dosen terkendala selama proses pendidikan Doktor

3. Beasiswa studi S3 dari Pemerintah semakin diperketat

4. Output tridarma terutama publikasi jurnal internasional bereputasi, buku ajar maupun buku referensi/monograph yang rendah.
1. Adanya mahasiswa yang mengundurkan diri dan mengambil cuti karena kondisi keuangan akibat Pandemic Covid-19

2. Rendahnya publikasi dosen dengan mahasiswa

3. Sedikitnya dosen yang melakukan kerjasama penelitian dan pengabdian masyarakat dengan mahasiswa

Jumlah pendaftar masih dibawah target kuota yang akan diterima

1. Dosen tidak termotivasi lanjut study S3

2. Studi dosen lebih dari 5 tahun

3. Dosen terkendala saat mengurus jafung ke Lektor Kepala 


\begin{tabular}{|c|c|c|c|}
\hline \multicolumn{4}{|c|}{ IDENTIFIKASI RISIKO } \\
\hline NO & $\begin{array}{l}\text { KEJADIAN } \\
\text { RISIKO }\end{array}$ & AKAR PENYEBAB & INDIKATOR RISIKO \\
\hline \multirow{6}{*}{4} & \multirow{6}{*}{$\begin{array}{l}\text { Adanya dosen } \\
\text { yang } \\
\text { melakukan } \\
\text { penelitian, } \\
\text { memiliki } \\
\text { publikasi jurnal } \\
\text { nasional/ } \\
\text { internasional/ } \\
\text { buku ajar/ buku } \\
\text { teks }\end{array}$} & $\begin{array}{l}\text { 5. Aktivitas dosen di dunia } \\
\text { akademisi } \\
\text { pembicara ilmiah, dll) masih } \\
\text { belum maksimal }\end{array}$ & \\
\hline & & $\begin{array}{l}\text { 1. Dosen sibuk mengajar } \\
\text { 2. Dosen sibuk bekerja (praktisi) } \\
\text { 3. Dosen kurang berminat/kurang } \\
\text { memiliki motivasi untuk menulis }\end{array}$ & $\begin{array}{lr}\text { 1. Dosen } & \text { yang } \\
\text { mengajukan } & \text { hibah } \\
\text { penelitian internal } & \text { ingai } \\
\text { sebagai } & \text { Ketua } \\
\text { Peneliti masih rendah }\end{array}$ \\
\hline & & 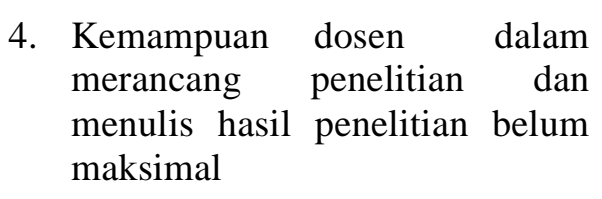 & $\begin{array}{l}\text { 2. Jumlah dosen yang } \\
\text { mengajukan hibah } \\
\text { penelitian eksternal } \\
\text { sangat minim }\end{array}$ \\
\hline & & $\begin{array}{l}\text { 5. } \begin{array}{l}\text { Kemampuan } \\
\text { melakukan dosen } \\
\text { rendah }\end{array} \text { publikasi } \\
\text { masih }\end{array}$ & $\begin{array}{l}\text { 3. Sedikitnya jumlah } \\
\text { buku ajar atau diktat } \\
\text { ajar yang dihasilkan }\end{array}$ \\
\hline & & 6. Topik artikel kurang up to date & $\begin{array}{l}\text { 4. Jumlah artikel yang } \\
\text { diterbitkan di jurnal } \\
\text { terindeks scopus } \\
\text { rendah }\end{array}$ \\
\hline & & & $\begin{array}{lr}\text { 5. Jumlah } & \text { sitasi } \\
\text { terhadap } & \text { artikel } \\
\text { dosen } & \text { rendah } \\
\text { 6. Jumlah } & \text { HAKI } \\
\text { sedikit } & \end{array}$ \\
\hline \multirow[t]{4}{*}{5} & \multirow[t]{4}{*}{$\begin{array}{l}\text { Terdapat do } \\
\text { yang } \\
\text { melakukan } \\
\text { kegiatan } \\
\text { pengabdian } \\
\text { masyarakat } \\
\text { output PKM }\end{array}$} & $\begin{array}{l}\text { 1. Dosen terlalu sibuk mengajar } \\
\text { 2. Dosen sibuk bekerja (praktisi) } \\
\text { 3. Dosen kurang termotivasi untuk } \\
\text { melakukan kegiatan pengabdian } \\
\text { masyarakat }\end{array}$ & $\begin{array}{l}\text { 1. Dosen yang } \\
\text { mengajukan hibah } \\
\text { pengabdian } \\
\text { masyarakat internal } \\
\text { sebagai Ketua PKM } \\
\text { masih sedikit. }\end{array}$ \\
\hline & & $\begin{array}{l}\text { 4. Kemampuan dosen dalam } \\
\text { merancang materi pengabdian } \\
\text { kepada masyarakat masih rendah }\end{array}$ & $\begin{array}{lr}\text { 2. Jumlah dosen } & \text { yang } \\
\text { mengajukan } & \text { hibah } \\
\text { eksternal } & \text { PKM }\end{array}$ \\
\hline & & $\begin{array}{l}\text { 5. Kemampuan dosen untuk } \\
\text { melakukan publikasi hasil } \\
\text { pengabdian kepada masyarakat } \\
\text { (buku PKM, pedoman, berita, } \\
\text { dll) masih minim }\end{array}$ & $\begin{array}{l}\text { sangat minim } \\
\text { 3. Belum adanya buku } \\
\text { yang dihasilkan } \\
\text { dosen dari kegiatan } \\
\text { PKM }\end{array}$ \\
\hline & & & $\begin{array}{l}\text { 4. Jumlah publikasi } \\
\text { artikel hasil PKM }\end{array}$ \\
\hline
\end{tabular}




\begin{tabular}{lll}
\hline NO KEJADIAN & AKAR PENYEBAB & INDIKATOR RISIKO \\
\hline RISIKO & $\begin{array}{l}\text { yang diterbitkan } \\
\text { masih rendah }\end{array}$ \\
& $\begin{array}{l}\text { Jumlah HAKI dari } \\
\text { output PKM masih } \\
\text { rendah }\end{array}$ \\
\hline
\end{tabular}

\section{Faktor Positif Dan Dampak}

Tabel 4. Faktor Positif dan Dampak

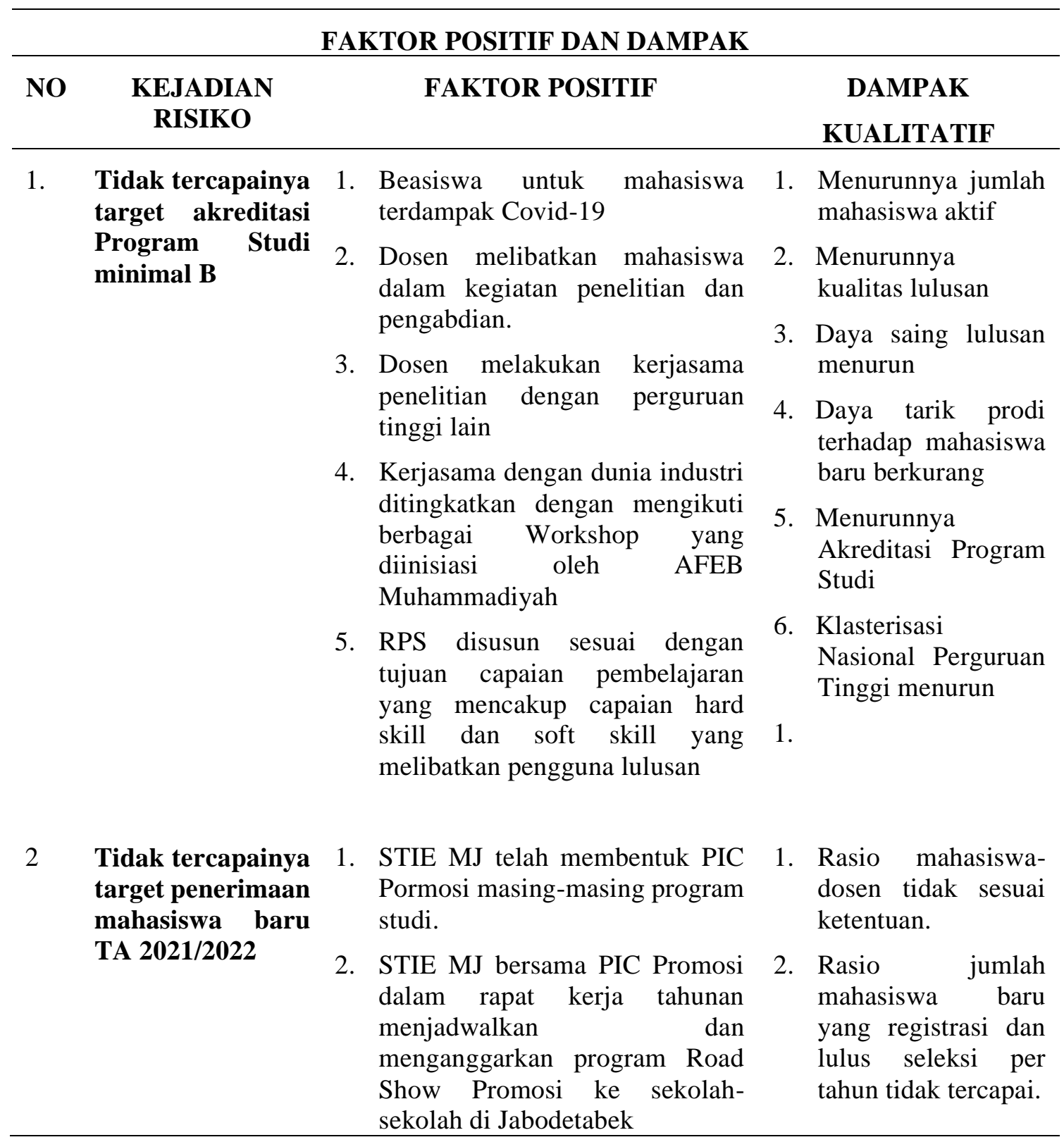




\begin{tabular}{|c|c|c|}
\hline & & FAKTOR POSITIF DAN DAMPAK \\
\hline NO & $\begin{array}{l}\text { KEJADIAN } \\
\text { RISIKO }\end{array}$ & FAKTOR POSITIF \\
\hline & & $\begin{array}{l}\text { 3. Adanya program beasiswa } \\
\text { internal/eksternal bagi } \\
\text { mahasiswa baru. } \\
\text { 4. STIEMJ memiliki website dan } \\
\text { media sosial sebagai media } \\
\text { promosi. }\end{array}$ \\
\hline 3 & $\begin{array}{lr}\text { Jumlah } & \text { Dosen } \\
\text { berpendidikan S3 } \\
\text { dan } & \text { Lektor } \\
\text { Kepala } & \text { dibawah } \\
\mathbf{5 0 \%} & \end{array}$ & $\begin{array}{l}\text { 1. Institusi menyediakan beasiswa } \\
\text { untuk dosen lanjut Studi S3 } \\
\text { 2. Institusi melakukan } \\
\text { pendampingan publikasi jurnal } \\
\text { internasional bereputasi } \\
\text { 3. Institusi memfasilitasi dan } \\
\text { membantu dosen dalam mengurus } \\
\text { kepangkatan melalui Sijali }\end{array}$ \\
\hline
\end{tabular}

4

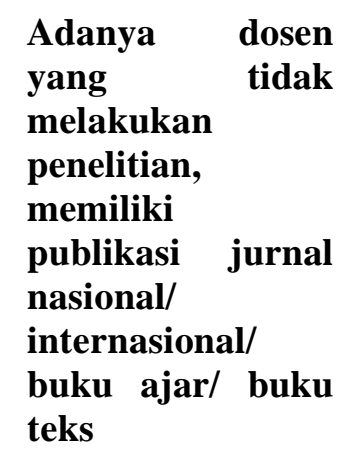

dosen 1. Pemberian insentif bagi dosen tidak yang memiliki publikasi jurnal, buku, HAKI, prosiding 2. Sosialisasi kepada mahasiswa dan dosen terkait artikel publikasi dari skripsi telah dilakukan namun minitoring dan evaluasi belum maksimal

$\begin{aligned} \text { dosen } & \text { 1. Pemberian insentif bagi dosen } \\ \text { tidak } & \text { yang memiliki publikasi jurnal, } \\ & \text { buku, HAKI, prosiding dari hasil } \\ & \text { PKM } \\ & \text { 2. Sosialisasi kepada dosen terkait } \\ \text { dan } & \begin{array}{l}\text { topik atau materi update yang } \\ \text { dibutuhkan oleh Masyarakat }\end{array}\end{aligned}$

\section{DAMPAK \\ KUALITATIF}

3. Terjadinya

penurunan Student Body dapat berdampak terhadap menurunnya akreditasi

4. Jadwal penerimaan mahasiswa baru diperpanjang.

1. Target Dosen berpendidikan S3 minimal $50 \%$ tidak tercapai

2. Target minimal jumlah Lektor Kepala tidak tercapai 3. Peringkat klasterisasi nasional perguruan tinggi menurun

1. Kenaikan jabatan fungsional dosen terhambat

2. Akreditasi program studi tidak maksimal 3. Peringkat klasterisasi Penelitian menurun 4. Peringkat klusterisasi Perguruan Tinggi Nasional menurun

1. Kenaikan jabatan fungsional dosen terhambat

2. Akreditasi program studi tidak maksimal 3. Peringkat klasterisasi pengabdian kepada masyarakat menurun 4. Peringkat klusterisasi Perguruan Tinggi Nasional menurun 
JURNAL AKUNTANSI, Vol. 10, No. 2, November (2021)

\section{Kriteria Dampak Kuantitatif}

Tabel 5. Kriteria Dampak Kuantitatif

\begin{tabular}{|c|c|c|c|c|c|c|}
\hline \multicolumn{7}{|c|}{ KRITERIA DAMPAK RISIKO } \\
\hline \multirow{2}{*}{$\begin{array}{l}\text { Inde } \\
x\end{array}$} & \multirow{2}{*}{ Dampak } & \multirow{2}{*}{ Deskripsi } & \multicolumn{2}{|c|}{ Target Pendapatan } & \multicolumn{2}{|c|}{ Target Anggaran Biaya } \\
\hline & & & $5 \%$ dari Target & Rp 6 Miliar & $80 \%$ dari Anggaran & Rp 300 Juta \\
\hline 5 & Catastrophic & Sangat Besar & $>0.8 \mathrm{BTR}$ & > Rp. 240 Juta & $>0.8 \mathrm{BTR}$ & > Rp. 200 Juta \\
\hline 4 & Significant & $\begin{array}{c}\text { Besar } \\
\text { (Signifikan) }\end{array}$ & $\begin{array}{c}0.6 \text { BTR }<x \leq 0.8 \\
\text { BTR }\end{array}$ & $\begin{array}{l}\text { Rp. } 180 \text { Juta }<x \leq \\
\text { Rp. } 240 \text { Juta }\end{array}$ & $0.6 \mathrm{BTR}<\mathrm{x} \leq 0.8 \mathrm{BTR}$ & $\begin{array}{c}\text { Rp. } 150 \text { Juta }<x \leq R p . \\
200 \text { Juta }\end{array}$ \\
\hline 3 & Moderate & Sedang & $\begin{array}{c}0.4 \text { BTR }<x \leq 0.6 \\
\text { BTR }\end{array}$ & $\begin{array}{l}\text { Rp. } 120 \text { Juta }<x \leq \\
\text { Rp. } 180 \text { Juta }\end{array}$ & $0.4 \mathrm{BTR}<\mathrm{x} \leq 0.6 \mathrm{BTR}$ & $\begin{array}{c}\text { Rp. } 100 \text { Juta }<x \leq \text { Rp. } \\
150 \text { Juta }\end{array}$ \\
\hline 2 & Minor & Kecil & $\begin{array}{c}0.2 \text { BTR }<x \leq 0.4 \\
\text { BTR }\end{array}$ & $\begin{array}{l}\text { Rp. } 60 \text { Juta }<x \leq \\
\text { Rp. } 120 \text { Juta }\end{array}$ & 0.2 BTR $<x \leq 0.4$ BTR & $\begin{array}{c}\text { Rp. } 50 \text { Juta }<x \leq \text { Rp. } \\
100 \text { Juta }\end{array}$ \\
\hline 1 & Insignificant & $\begin{array}{l}\text { Sangat Kecil } \\
\text { (Tidak } \\
\text { Signifikan) }\end{array}$ & $<0.2$ BTR & < Rp. 60 Juta & $<0.2 \mathrm{BTR}$ & $<$ Rp. 50 Juta \\
\hline
\end{tabular}

\section{Kriteria Dampak Kualitatif}

Tabel 6. Kriteria Dampak Kuantitatif

\begin{tabular}{|c|c|c|c|c|c|}
\hline \multicolumn{6}{|c|}{ KRITERIA DAMPAK RISIKO PERUSAHAAN } \\
\hline Index & Dampak & Deskripsi & $\begin{array}{c}\text { Dampak Pada Sasaran Strategis } \\
\text { Organisasi } \\
\text { (Kualitatif) }\end{array}$ & $\begin{array}{c}\text { Dampak Pada Klasterisasi Nasional PT } \\
\text { (Kualitatif) }\end{array}$ & $\begin{array}{c}\text { Dampak Pada Reputasi-Akreditasi } \\
\text { Prodi } \\
\text { (Kualitatif) }\end{array}$ \\
\hline 5 & Catastrophic & Sangat Besar & $\begin{array}{l}\text { Tidak Tercapainya Sasaran dan } \\
\text { Kegagalan Mencapai Kinerja }\end{array}$ & Tidak memiliki pemeringkatan klaster & Akreditasi NA \\
\hline 4 & Significant & $\begin{array}{c}\text { Besar } \\
\text { (Signifikan) }\end{array}$ & $\begin{array}{c}\text { Tertundanya Tercapainya Sasaran } \\
\text { secara signifikan, Pencapaian Kinerja } \\
\text { jauh di bawah target }\end{array}$ & Klasterisasi turun menjadi Klaster 5 & Akreditasi jadi C \\
\hline 3 & Moderate & Sedang & $\begin{array}{c}\text { Tertundanya Tercapainya Sasaran } \\
\text { cukup besar, Pencapaian Kinerja di } \\
\text { bawah target }\end{array}$ & $\begin{array}{c}\text { Klaster } 4 \text { dengan nilai yang menurun } \\
\text { dari nilai sebelumnya }\end{array}$ & $\begin{array}{l}\text { Akreditas tetap B dan nilainya turun } \\
\text { dari nilai sebelumnya. }\end{array}$ \\
\hline 2 & Minor & Kecil & $\begin{array}{c}\text { Tercapainya Sasaran hanya sedikit di } \\
\text { bawah target, target kinerja sedikit di } \\
\text { bawah target }\end{array}$ & $\begin{array}{c}\text { Klaster } 4 \text { dengan nilai yang tetap dari } \\
\text { nilai sebelumnya }\end{array}$ & $\begin{array}{c}\text { Akreditas tetap B dan nilainya tetap } \\
\text { dari nilai sebelumnya. }\end{array}$ \\
\hline 1 & Insignificant & $\begin{array}{c}\text { Sangat Kecil } \\
\text { (Tidak Signifikan) }\end{array}$ & $\begin{array}{c}\text { Hanya berdampak sangat kecil pada } \\
\text { tercapainya sasaran, target kinerja } \\
\text { masih mampu dicapai }\end{array}$ & $\begin{array}{c}\text { Klaster } 4 \text { dengan nilai yang meningkat } \\
\text { dari nilai sebelumnya }\end{array}$ & $\begin{array}{l}\text { Akreditasi tetap B dan nilainya } \\
\text { meningkat dari nilai sebelumnya. }\end{array}$ \\
\hline
\end{tabular}


JURNAL AKUNTANSI, Vol. 10, No. 2, November (2021)

\section{Risiko Inherent}

Tabel 7. Risiko Inherent

\begin{tabular}{|c|c|c|c|c|c|}
\hline NO & KEJADIAN RISIKO & PROBABILITAS & DAMPAK & SKOR & TINGKAT RISIKO \\
\hline 1. & $\begin{array}{l}\text { Tidak tercapainya target akreditasi } \\
\text { Program Studi minimal B }\end{array}$ & $4=$ Besar & $4=$ Berat & 16 & EXTREME HIGH \\
\hline 2. & $\begin{array}{l}\text { Tidak tercapainya target penerimaan } \\
\text { mahasiswa baru TA 2021/2022 }\end{array}$ & $5=$ Sangat Besar & $\begin{array}{l}5=\text { Sangat } \\
\text { Berat }\end{array}$ & 25 & EXTREME HIGH \\
\hline 3. & $\begin{array}{l}\text { Jumlah Dosen berpendidikan \$3 dan } \\
\text { Lektor Kepala dibawah } 50 \%\end{array}$ & $4=$ Besar & $4=$ Berat & 16 & EXTREME HIGH \\
\hline 4. & $\begin{array}{l}\text { Terdapat dosen yang tidak melakukan } \\
\text { penelitian, memiliki publikasi jurnal } \\
\text { nasional/ internasional/ buku ajar/ } \\
\text { buku teks }\end{array}$ & $5=$ Besar & $\begin{array}{l}4=\text { Sangat } \\
\text { Berat }\end{array}$ & 20 & EXTREME HIGH \\
\hline 5. & $\begin{array}{l}\text { Terdapat dosen yang tidak melakukan } \\
\text { kegiatan pengabdian masyarakat } \\
\text { dan output PKM }\end{array}$ & $4=$ Besar & $3=$ Ringan & 12 & HIGH RISK \\
\hline
\end{tabular}

\section{Profile Risiko Inherent}

Tabel 8. Profile Risiko Inherent

\begin{tabular}{|c|c|c|c|c|c|c|}
\hline \multirow{5}{*}{ 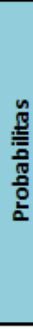 } & $\begin{array}{c}5=\text { Sangat Besar } \\
(>80 \%)\end{array}$ & & & & & \\
\hline & $\begin{array}{c}4=\text { Besar } \\
(60 \%<p<80 \%)\end{array}$ & & & & & \\
\hline & $\begin{array}{c}3=\text { Sedang } \\
(40 \%<p \leq 60 \%)\end{array}$ & & & & & \\
\hline & $\begin{array}{c}2=\text { Kecil } \\
(10 \%<p<40 \%)\end{array}$ & & & & & \\
\hline & $\begin{array}{c}1=\text { Sangat Kecil } \\
\leq 10 \%\end{array}$ & & & & & \\
\hline & Dampak Risiko Finansial & $<0.2 \mathrm{BTR}$ & $0.2 \mathrm{BTR}<\mathrm{x} \leq 0.4 \mathrm{BTR}$ & $0.4 \mathrm{~B} T \mathrm{R}<\mathrm{x} \leq 0.6 \mathrm{BTR}$ & $0.6 \mathrm{BTR}<\mathrm{x} \leq 0.8 \mathrm{BTR}$ & $>0.8 \mathrm{BTR}$ \\
\hline & $\begin{array}{c}\text { Dampak Pada Sasaran } \\
\text { Strategis Organisasi } \\
\text { (Kualitatif) }\end{array}$ & $\begin{array}{c}\text { Hanya berdampak } \\
\text { sangat kecil pada } \\
\text { tercapainya sasaran, } \\
\text { target kinerja masih } \\
\text { mampu dicapai }\end{array}$ & $\begin{array}{l}\text { Tercapainya Sasaran } \\
\text { hanya sedikit di bawah } \\
\text { target, target kinerja } \\
\text { sedikit di bawah target }\end{array}$ & $\begin{array}{c}\text { Tertundanya } \\
\text { Tercapainya Sasaran } \\
\text { cukup besar, } \\
\text { Pencapaian Kinerja di } \\
\text { bawah target }\end{array}$ & $\begin{array}{c}\text { Tertundanya } \\
\text { Tercapainya Sasaran } \\
\text { secara signifikan, } \\
\text { Pencapaian Kinerja jauh } \\
\text { di bawah target }\end{array}$ & $\begin{array}{c}\text { Tidak Tercapainya } \\
\text { Sasaran dan Kegagalan } \\
\text { Mencapai Kinerja }\end{array}$ \\
\hline & $\begin{array}{c}\text { Dampak Pada Klasterisasi } \\
\text { Nasional PT }\end{array}$ & $\begin{array}{c}\text { Klaster } 4 \text { dengan nilai } \\
\text { yang meningkat dari } \\
\text { nilai sebelumnya }\end{array}$ & $\begin{array}{l}\text { Klaster } 4 \text { dengan nilai } \\
\text { yang tetap dari nilai } \\
\text { sebelumnya }\end{array}$ & $\begin{array}{l}\text { Klaster } 4 \text { dengan nilai } \\
\text { yang menurun dari nilai } \\
\text { sebelumnya }\end{array}$ & $\begin{array}{l}\text { Klasterisasi turun } \\
\text { menjadi Klaster } 5\end{array}$ & $\begin{array}{c}\text { Tidak memiliki } \\
\text { pemeringkatan klaster }\end{array}$ \\
\hline & $\begin{array}{l}\text { Dampak Pada Reputasi- } \\
\text { Akreditasi Prodi (Kualitatif) }\end{array}$ & \begin{tabular}{|c|} 
Akreditasi tetap B dan \\
nilainya meningkat dari \\
nilai sebelumnya.
\end{tabular} & \begin{tabular}{|c|} 
Akreditas tetap B dan \\
nilainya tetap dari nilai \\
sebelumnya. \\
\end{tabular} & \begin{tabular}{|c|} 
Akreditas tetap B dan \\
nilainya turun dari nilai \\
sebelumnya. \\
\end{tabular} & Akreditasi jadi C & Akreditasi NA \\
\hline & & 1 = Ringan Sekali & $2=$ Ringan & $3=$ Sedang & $4=$ Berat & $5=$ Sangat Berat \\
\hline & & & & Dampak & & \\
\hline
\end{tabular}




\section{Top Risk Event}

Tabel 9. Top Risk Event

\begin{tabular}{|c|c|c|c|c|c|c|c|}
\hline No. & KODE RISIKO & $\begin{array}{l}\text { NO PADA RISK } \\
\text { REGISTER }\end{array}$ & $\begin{array}{c}\text { TANGGAL } \\
\text { IDENTIIFIKASI RISIKO }\end{array}$ & KEADIAN RISIKO (RISK EVENT) & Dampak Inherent & PEMILIK RISIKO & $\begin{array}{l}\text { DEPARTMENT (UNIT } \\
\text { KERUA) }\end{array}$ \\
\hline 1 & BID3-KMW & 2 & 2021 & $\begin{array}{l}\text { Tidak tercapainya target penerimaan mahasiswa } \\
\text { baru TA 2021/2022 }\end{array}$ & $5=$ Sangat Berat & $\begin{array}{l}\text { 1. Sutar, S.E., MM } \\
\text { 2. Ahmad Darda, MM } \\
\text { 3. Moch. Rizal, MM }\end{array}$ & Kemahasiswaan \\
\hline 2 & BID1-PRD & 1 & 2021 & $\begin{array}{l}\text { Tidak tercapainya target akreditasi Program Studi } \\
\text { minimal B }\end{array}$ & $4=$ Berat & \begin{tabular}{|c|} 
Marlianingrum \\
2. Moch Rizal, MM \\
3. Hidayat Darwis, MM \\
4. Zaenudin, M.Si. \\
5. Imam Suprapta, M.M. \\
\end{tabular} & Program Studi \\
\hline 3 & BID2-SDM & 3 & 2021 & $\begin{array}{l}\text { Jumlah Dosen berpendidikan S3 dan Lektor Kepala } \\
\text { dibawah } 50 \%\end{array}$ & $4=$ Berat & $\begin{array}{l}\text { 1. Dr. Ramdany, } \\
\text { SE.Ak.M.Ak., CPA } \\
\text { 2. Dr. Arlis Dewi } \\
\text { Kuraesin, M.Ak.CA }\end{array}$ & Sumber Daya Manusia \\
\hline 4 & BID1-LEMLIT & 4 & 2021 & $\begin{array}{l}\text { Terdapat dosen yang tidak melakukan penelitian, } \\
\text { memiliki publikasi jurnal nasional/ internasional/ } \\
\text { buku ajar/ buku teks }\end{array}$ & $4=$ Berat & $\begin{array}{l}\text { 1. Dr. Peggy Ratna } \\
\text { Marlianingrum } \\
\text { 2. Dr. Rita Yuni } \\
\text { Mulyanti, MM }\end{array}$ & Lembaga Penelitian \\
\hline 5 & BID1-LPM & 5 & 2021 & $\begin{array}{l}\text { Terdapat dosen yang tidak melakukan kegiatan } \\
\text { pengabdian masyarakat dan output PKM }\end{array}$ & $3=$ Sedang & $\begin{array}{l}\text { 1. Dr. Peggy Ratna } \\
\text { Marlianingrum } \\
\text { 2. Muhamad Lutfi, MM }\end{array}$ & $\begin{array}{l}\text { Lembaga Pengabdian } \\
\text { Masyarakat }\end{array}$ \\
\hline
\end{tabular}

Berdasarkan analisis top event risk dari kelima risiko, risiko tertinggi adalah tidak tercapainya target penerimaan mahasiswa baru TA 2021/2022 dari Unit Kemahasiswaan Bidang III, berturut-turut risiko tertinggi berikutnya adalah tidak tercapainya target akreditasi program study minimal B, jumlah dosen berpendidikan S3 dan Lektor kepala dibawah 50\% dari unit SDM, terdapat dosen yang tidak melakukan penelitian, memiliki publikasi jurnal nasional/internasional/buku ajar/buku teks dari Lembaga penelitian, dan risiko terendah adalah terdapat dosen yang tidak melakukan kegiatan pengabdian masyarakat dan output PKM dari Lembaga Pengabdian Masyarakat.

\section{Mitigasi Risiko}

Pada tahapan penelitian ini, tahap yang dilakukan adalah melakukan mitigasi risiko berdasarkan tingkat (level) risiko dan evaluasi risiko yang telah dilakukan. Perencanaan mitigasi risiko yang dilakukan maka pendekatan yang diguanakan adalah risk register agar, perencanaan serta pengelolahan risiko yang ada dapat dialokasikan kepada penanggungjawab dari setiap kegiatan yang memiliki risiko. Risk register merupakan dokumen perencanaan pengelolahan risiko yang dapat dilakukan oleh karena itu risk register dapat membantu proses pengulasan serta pengidentifikasian bagi Departemen agar dapat melakukan pengawasan (monitoring) ada proses pengolahan risiko terhadap pengajarana yang ada pada STIE Muhammadiyah Jakarta.

Berikut ini adalah rencana Tindakan mitigasi yang dilakukan oleh risk owner:

Tabel 10. Mitigasi Risiko

\begin{tabular}{lllll}
\hline NO & $\begin{array}{c}\text { KEJADIAN } \\
\text { RISIKO }\end{array}$ & RISK OWNER & RENCANA TINDAKAN MITIGASI \\
\hline 1. & $\begin{array}{l}\text { Tidak tercapainya } \\
\text { target akreditasi } \\
\begin{array}{l}\text { Program Studi } \\
\text { minimal B }\end{array}\end{array}$ & $\begin{array}{l}\text { 1. Wakil Ketua I } \\
\text { 2. Ketua Prodi S1 } \\
\text { Manajemen }\end{array}$ & $\begin{array}{l}\text { 1. } \\
\text { Mengupayakan beasiswa untuk } \\
\text { mahasiswa terdampak Covid-19 } \\
\text { bekerjasama institusi lain }\end{array}$ \\
\hline
\end{tabular}




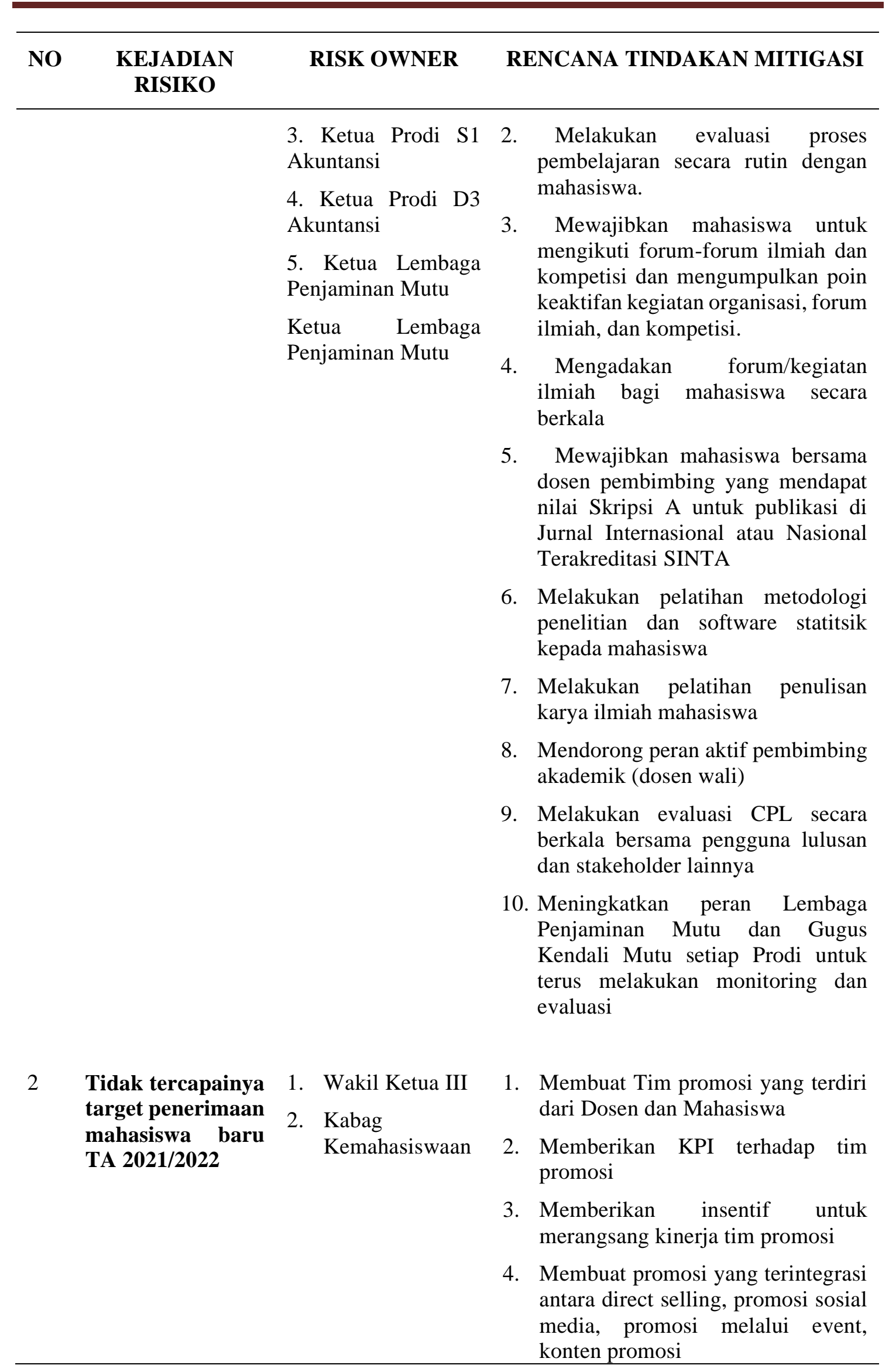




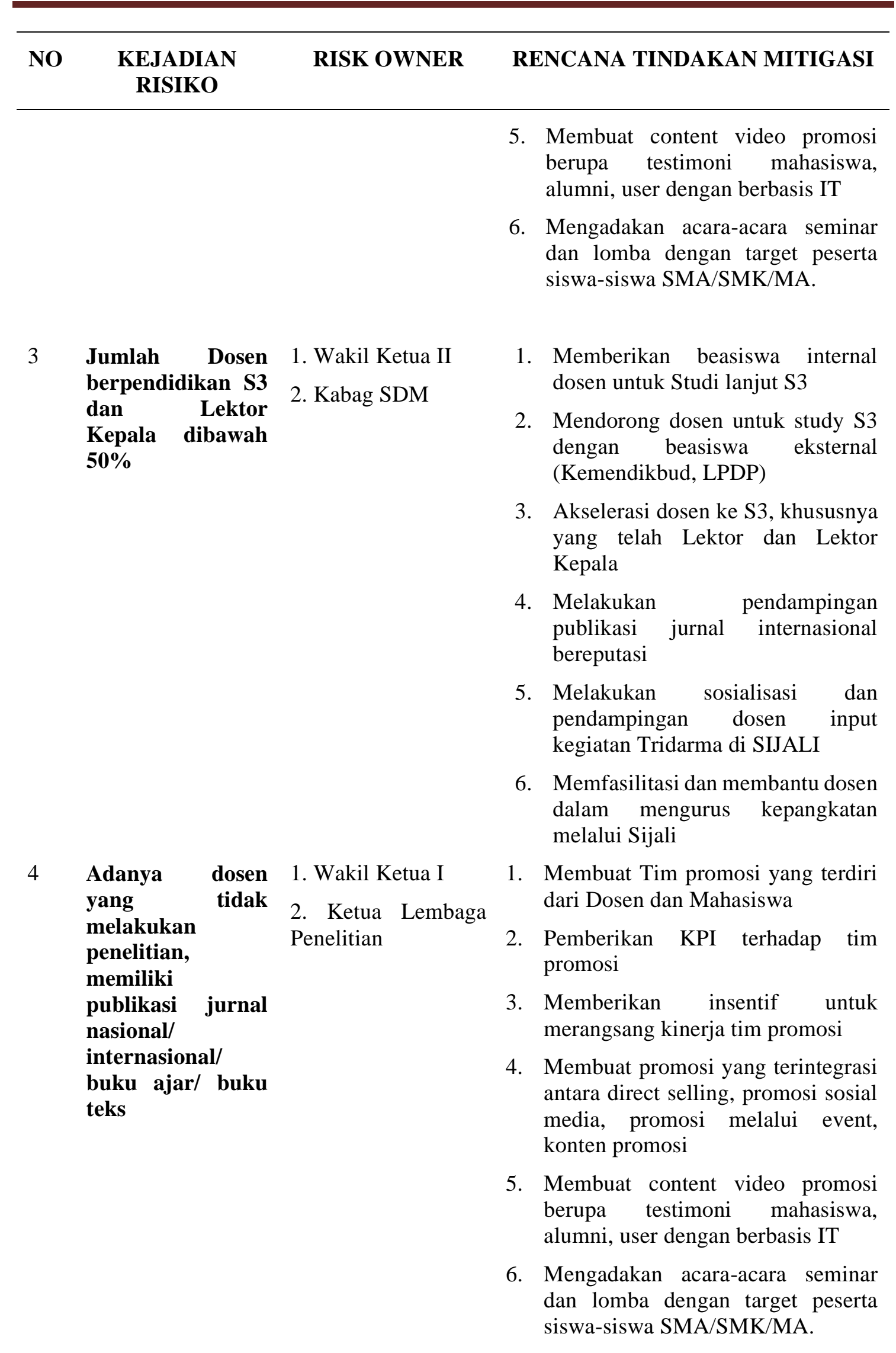


JURNAL AKUNTANSI, Vol. 10, No. 2, November (2021)

\begin{tabular}{|c|c|c|c|}
\hline NO & $\begin{array}{l}\text { KEJADIAN } \\
\text { RISIKO }\end{array}$ & RISK OWNER & RENCANA TINDAKAN MITIGASI \\
\hline 5 & $\begin{array}{lr}\text { Terdapat } & \text { dosen } \\
\text { yang } & \text { tidak } \\
\text { melakukan } & \\
\text { kegiatan } & \\
\text { pengabdian } & \\
\text { masyarakat dan } & \\
\text { output PKM } & \end{array}$ & $\begin{array}{l}\text { 1. Wakil Ketua I } \\
\text { 2. Ketua Lembaga } \\
\text { Pengabdian } \\
\text { Masyarakat }\end{array}$ & $\begin{array}{l}\text { 1. Memberikan beasiswa internal } \\
\text { dosen untuk Studi lanjut S3 } \\
\text { 2. Mendorong dosen untuk study S3 } \\
\text { dengan beasiswa eksternal } \\
\text { (Kemendikbud, LPDP) } \\
\text { 3. Akselerasi dosen ke S3, khususnya } \\
\text { yang telah Lektor dan Lektor Kepala } \\
\text { 4. Melakukan pendampingan publikasi } \\
\text { jurnal internasional bereputasi } \\
\text { 5. Melakukan sosialisasi dan } \\
\text { pendampingan dosen input kegiatan } \\
\text { Tridarma di SIJALI } \\
\text { 6. Memfasilitasi dan membantu dosen } \\
\text { dalam mengurus kepangkatan } \\
\text { melalui Sijali }\end{array}$ \\
\hline
\end{tabular}

\section{Dampak Financial}

Tabel 11. Dampak Financial

\begin{tabular}{|c|c|c|c|c|c|c|c|c|}
\hline \multirow[t]{2}{*}{ NO } & \multirow[t]{2}{*}{ KEJADIAN RISIKO } & \multicolumn{3}{|c|}{ RISIKO INHERENT } & \multirow{2}{*}{$\begin{array}{c}\text { Biava } \\
\text { Penangan } \\
\text { an Risiko }\end{array}$} & \multicolumn{3}{|c|}{ RISIKO RESIDUAL } \\
\hline & & PROB. & $\begin{array}{c}\text { DAMPAK } \\
\text { FINANSIAL } \\
\text { Rp. }\end{array}$ & $\begin{array}{l}\text { NILAI BERSIH } \\
\text { RISIKO } \\
\text { Rp. }\end{array}$ & & PROB. & $\begin{array}{l}\text { DAMPAK } \\
\text { FINANSIAL }\end{array}$ & $\begin{array}{l}\mathrm{NILAI} \\
\text { BERSIH } \\
\text { RISIKO }\end{array}$ \\
\hline 1. & $\begin{array}{c}\text { Tidak tercapainya } \\
\text { target akreditasi } \\
\text { Program Studi minimal } \\
\text { B }\end{array}$ & $70 \%$ & 500 Juta & 350 Juta & 170 Juta & $5 \%$ & 100 Juta & 5 Juta \\
\hline 2. & $\begin{array}{l}\text { Tidak tercapainya target } \\
\text { penerimaan mahasiswa } \\
\text { baru TA 2021/2022 }\end{array}$ & $90 \%$ & 600 Juta & 540 Juta & 215 Juta & $50 \%$ & 120 Juta & 60 Juta \\
\hline 3. & $\begin{array}{l}\text { Jumlah Dosen } \\
\text { berpendidikan S3 dan } \\
\text { Lektor Kepala dibawah } \\
50 \%\end{array}$ & $70 \%$ & 500 Juta & 350 Juta & 260 Juta & $50 \%$ & 100 Juta & 50 Juta \\
\hline 4. & $\begin{array}{l}\text { Terdapat dosen yang } \\
\text { tidak melakukan } \\
\text { penelitian dan output }\end{array}$ & $90 \%$ & 150 Juta & 135 Juta & 45 Juta & $25 \%$ & 30 Juta & 7,5 Juta \\
\hline 5. & $\begin{array}{l}\text { Terdapat dosen yang } \\
\text { tidak melakukan } \\
\text { kegiatan pengabdian } \\
\text { masyarakat dan output }\end{array}$ & $70 \%$ & 100 Juta & 70 Juta & 35 Juta & $25 \%$ & 20 Juta & 5 Juta \\
\hline
\end{tabular}


JURNAL AKUNTANSI, Vol. 10, No. 2, November (2021)

\section{Risiko Residual}

Tabel 12. Risiko Residual

\begin{tabular}{|c|c|c|c|c|c|}
\hline NO & KEJADIAN RISIKO & $\begin{array}{l}\text { PROBABILIT } \\
\text { AS }\end{array}$ & DAMPAK & SKOR & $\begin{array}{l}\text { TINGKAT } \\
\text { RISIKO }\end{array}$ \\
\hline 1 & $\begin{array}{l}\text { Tidak tercapainya target } \\
\text { akreditasi Program } \\
\text { Studi minimal B }\end{array}$ & $1=$ Sangat Kecil & $2=$ Ringan & 2 & LOW RISK \\
\hline 2 & $\begin{array}{l}\text { Tidak tercapainya target } \\
\text { penerimaan mahasiswa } \\
\text { baru TA 2021/2022 }\end{array}$ & $3=$ Sedang & $3=$ Sedang & 9 & HIGH RISK \\
\hline 3 & $\begin{array}{lr}\text { Jumlah } & \text { Dosen } \\
\text { berpendidikan } & \text { S3 dan } \\
\text { Lektor Kepala dibawah } \\
50 \%\end{array}$ & $3=$ Sedang & $3=$ Sedang & 9 & HIGH RISK \\
\hline 4 & $\begin{array}{l}\text { Terdapat dosen yang tidak } \\
\text { melakukan penelitian, } \\
\text { memiliki publikasi jurnal } \\
\text { nasional/ internasional/ } \\
\text { buku ajar/ buku teks }\end{array}$ & $2=$ Ringan & $2=$ Ringan & 4 & $\begin{array}{l}\text { MEDIUM } \\
\text { RISK }\end{array}$ \\
\hline 5 & $\begin{array}{l}\text { Terdapat dosen yang tidak } \\
\text { melakukan kegiatan } \\
\text { pengabdian masyarakat } \\
\text { dan output PKM }\end{array}$ & $2=$ Ringan & $\begin{array}{l}1=\text { Sangat } \\
\text { Kecil }\end{array}$ & 2 & LOW RISK \\
\hline
\end{tabular}




\section{Profil Risiko Residual}

Tabel 13. Profil Risiko Residual

\begin{tabular}{|c|c|c|c|c|c|c|}
\hline \multirow{5}{*}{ 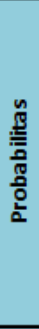 } & $\begin{array}{c}5=\text { Sangat Besar } \\
(>80 \%)\end{array}$ & & & & & \\
\hline & $\begin{array}{c}4=\text { Besar } \\
(60 \%<p<80 \%)\end{array}$ & & & & & \\
\hline & $\begin{array}{c}3=\text { Sedang } \\
(40 \%<p \leq 60 \%)\end{array}$ & & & & & \\
\hline & $\begin{array}{c}2=\text { Kecil } \\
(10 \%<p<40 \%)\end{array}$ & & & & & \\
\hline & $\begin{array}{c}1=\text { Sangat Kecil } \\
\leq 10 \%\end{array}$ & & & & & \\
\hline & Dampak Risiko Finansial & $<0.2 \mathrm{BTR}$ & $0.2 \mathrm{BTR}<\mathrm{x} \leq 0.4 \mathrm{BTR}$ & 0.4 BTR $<x \leq 0.6$ BTR & $0.6 \mathrm{BTR}<\mathrm{x} \leq 0.8 \mathrm{BTR}$ & $>0.8 \mathrm{BTR}$ \\
\hline & $\begin{array}{c}\text { Dampak Pada Sasaran } \\
\text { Strategis Organisasi } \\
\text { (Kualitatif) }\end{array}$ & $\begin{array}{l}\text { Hanya berdampak } \\
\text { sangat kecil pada } \\
\text { tercapainya sasaran, } \\
\text { target kinerja masih }\end{array}$ & $\begin{array}{c}\text { Tercapainya Sasaran } \\
\text { hanya sedikit di bawah } \\
\text { target, target kinerja } \\
\text { sedikit di bawah target }\end{array}$ & $\begin{array}{c}\text { Tertundanya } \\
\text { Tercapainya Sasaran } \\
\text { cukup besar, } \\
\text { Pencapaian Kinerja di }\end{array}$ & $\begin{array}{c}\text { Tertundanya } \\
\text { Tercapainya Sasaran } \\
\text { secara signifikan, } \\
\text { Pencapaian Kinerja jauh } \\
\end{array}$ & $\begin{array}{l}\text { Tidak Tercapainya } \\
\text { Sasaran dan Kegagalan } \\
\text { Mencapai Kinerja }\end{array}$ \\
\hline & $\begin{array}{c}\text { Dampak Pada Klasterisasi } \\
\text { Nasional PT }\end{array}$ & $\begin{array}{c}\text { Klaster } 4 \text { dengan nilai } \\
\text { yang meningkat dari } \\
\text { nilai sebelumnya }\end{array}$ & $\begin{array}{c}\text { Klaster } 4 \text { dengan nilai } \\
\text { yang tetap dari nilai } \\
\text { sebelumnya }\end{array}$ & $\begin{array}{c}\text { Klaster } 4 \text { dengan nilai } \\
\text { yang menurun dari nilai } \\
\text { sebelumnya } \\
\end{array}$ & $\begin{array}{l}\text { Klasterisasi turun } \\
\text { menjadi Klaster } 5\end{array}$ & $\begin{array}{c}\text { Tidak memiliki } \\
\text { pemeringkatan klaster }\end{array}$ \\
\hline & $\begin{array}{c}\text { Dampak Pada Reputasi- } \\
\text { Akreditasi Prodi } \\
\text { (Kualitatifl }\end{array}$ & $\begin{array}{c}\text { Akreditasi tetap B dan } \\
\text { nilainya meningkat dari } \\
\text { nilai sebelumnya. }\end{array}$ & $\begin{array}{c}\text { Akreditas tetap B dan } \\
\text { nilainya tetap dari nilai } \\
\text { sebelumnya. } \\
\end{array}$ & $\begin{array}{c}\text { Akreditas tetap B dan } \\
\text { nilainya turun dari nilai } \\
\text { sebelumnya. } \\
\end{array}$ & Akreditasi jadi C & Akreditasi NA \\
\hline & & 1 = Ringan Sekali & 2 = Ringan & $3=$ Sedang & $4=$ Berat & 5 = Sangat Berat \\
\hline & & & & Dampak & & \\
\hline
\end{tabular}

Berdasarkan risk profile dari kelima identifikasi risiko, risiko 1 berdampak kualitatif terhadap penurunan peringkat akreditasi, risiko kedua dan ketiga berdampak terhadap tidak tercapainya sasaran kinerja, risiko keempat dan kelima dapat berdampak terhadap penurunan klasterisasi Nasional Perguruan Tinggi. Dampak kuantitatif Risiko 1-3 berdampak terhadap kerugian institusi, risiko no. 4 dan 5 berdampak terhadap rendahnya penyerapan anggaran (cost center).

\section{Risk Appetite}

Risk appetite menurut COSO merupakan risiko yang dapat diterima oleh organisasi untuk mencapai tujuannya. Setiap organisasi yang berdiri selalu menghadapi resiko, dan resiko tersebut harus diambil untuk pencapaian tujuannya. Penerapan Risk Appetite pada dasarnya akan mempengaruhi budaya dan gaya operasional pada organisasi. Ketika suatu organisasi memutuskan memiliki tujuan yang agresif, tentu selera resiko yang diambilnya lebih tinggi; sebaliknya bila organisasi memutuskan tujuannya lebih konservatif, maka selera resikonya pasti lebih rendah.

COSO menekankan bahwa suatu organisasi harus mempertimbangkan selera resikonya pada saat organisasi tersebut mencanangkan tujuannya. Ada 3 langkah yang bisa ditempuh untuk menentukan selera resiko yang akan dipilih:

1. Membuat/menetapkan Risk Appetite

Tidak ada standar universal untuk penentuan selera resiko yang berlaku bagi semua organisasi. Selera resiko harus disesuaikan dengan tujuan organisasi. Tidak ada selera resiko yang "benar". Manajemen dan Pimpinan Tinggi dapat memilih selera resiko yang sesuai, dengan memahami imbal balik terhadap organisasi atas pilihan tersebut.

2. Mengkomunikasikan Risk Appetite tersebut 
Membuat Risk Appetite Statement secara makro namun cukup deskriptif untuk dikomunikasikan kepada unit-unit di organisasi agar manajemen bisa mengelola resikonya konsisten dengan selera resiko yang sudah ditetapkan.

3. Monitor dan Update Risk Appetite

Ketika selera resiko sudah ditetapkan, tidak bisa hanya dibiarkan berjalan saja. Perlu untuk direviu dan dilihat sejauh mana operasionalisasi pada unit-unit organisasi mengacu pada selera resiko tersebut. Selain manajemen, fungsi Internal Auditor untuk melihat sampai sejauh mana keefektifan dari penerapan selera resiko tersebut juga diperlukan. Dengan hal ini akan terjadi monitoring \& evaluasi secara berkesinambungan atas selera resiko tersebut.

Berikut ini adalah hasil analisis dari risk appetite di STIE Muhammadiyah Jakarta:

Tabel 14. hasil analisis dari risk appetite di STIE Muhammadiyah Jakarta

\begin{tabular}{|c|c|c|c|c|c|c} 
No. & Kode Risiko & $\begin{array}{c}\text { No pada Risk } \\
\text { Register }\end{array}$ & Kejadian Risiko (Risk Event) & $\begin{array}{c}\text { Status Risiko } \\
\text { Inherent }\end{array}$ & $\begin{array}{c}\text { Status Risiko } \\
\text { Residual }\end{array}$ & $\begin{array}{c}\text { Target } \\
\text { Risiko/Risk } \\
\text { Appetite }\end{array}$ \\
\hline 1 & BID3-KMW & 2 & Tidak tercapainya target penerimaan mahasiswa baru TA 2021/2022 & EXTREME HIGH & HIGH RISK & LOW RISK \\
\hline 2 & BID1-LEMLIT & 4 & Terdapat dosen yang tidak melakukan penelitian, memiliki publikasi jurnal nasion & EXTREME HIGH & MEDIUM RISK & LOW RISK \\
\hline 3 & BID1-PRD & 1 & Tidak tercapainya target akreditasi Program Studi minimal B & EXTREME HIGH & LOW RISK & LOW RISK \\
\hline 4 & BID2-SDM & 3 & Jumlah Dosen berpendidikan S3 dan Lektor Kepala dibawah 50\% & EXTREME HIGH & HIGH RISK & LOW RISK \\
\hline 5 & BID1-LPM & 5 & Terdapat dosen yang tidak melakukan kegiatan pengabdian masyarakat dan outh & HIGH RISK & LOW RISK & LOW RISK
\end{tabular}

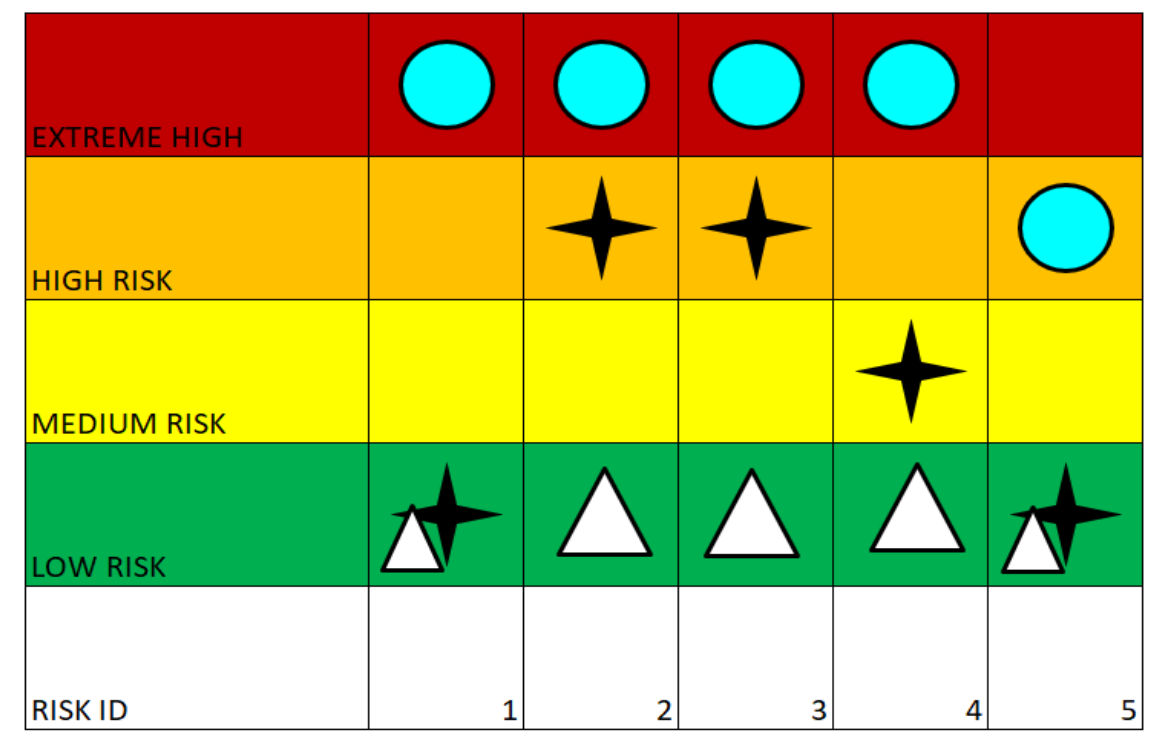

Gambar 3. Risk Appetite STIE Muhammadiyah Jakarta (2021)

Berdasarkan hasil analisis di STIE Muhammadiyah Jakarta, semua risiko datat dimitigasi dengan baik, namun hanya ada 2 risiko yang mencapai target yaitu risiko 1 dan risiko 5, sementara risiko 2, 3, dan 4 tidak sesuai target risiko yang diharapkan (risk appetite). Beberapa risiko memerlukan penangan dalam waktu yang tidak singkat seperti risiko 4 yang dapat mengakibatkan risiko residual tidak sesuai dengan target risiko yang diharapkan (risk appetite), sehingga diperlukan penanganan risiko secara berkelanjutan. 


\section{PENUTUP}

\section{Simpulan}

Risiko Inherent yang melekat pada STIE Muhammadiyah Jakarta harus diidentifikasi sedini mungkin dengan melihat rencana kerja dan kontrak kinerja dengan Yayasan (Majlis Litbang PP Muhammadiyah), dan Standar SPMI STIE Muhammadiyah Jakarta, serta melalui brainstorming dengan segenap sivitas Akademika, kemudian dibuat Risk Register untuk mencari solusi atau mitigasi risiko agar tidak terjadi kerugian pada Institusi. Berdasarkan hasil identifikasi risiko, terdapat 5 risiko inherent yang bisa berdampak terhadap sustainability STIE MJ.

Berdasarkan risk profile dari kelima identifikasi risiko, risiko 1 berdampak kualitatif terhadap penurunan peringkat akreditasi, risiko kedua dan ketiga berdampak terhadap tidak tercapainya sasaran kinerja, risiko keempat dan kelima dapat berdampak terhadap penurunan klasterisasi Nasional Perguruan Tinggi. Dampak kuantitatif Risiko 1-3 berdampak terhadap kerugian institusi, risiko no. 4 dan 5 berdampak terhadap rendahnya penyerapan anggaran (cost center).

Setelah risiko inherent dimitigasi diharapkan risiko residual dengan tingkat kerugian dapat ditekan seminimal mungkin. Namun, karena beberapa risiko memerlukan penangan dalam waktu yang tidak singkat seperti risiko 4 dapat mengakibatkan risiko residual tidak sesuai dengan target risiko yang diharapkan (risk appetite), sehingga diperlukan penanganan risiko secara berkelanjutan.

\section{Saran}

Penelitian ini memiliki keterbatasan yaitu identifikasi risiko tidak dilakukan secara mendalam pada semua unit kerja. Penelitian mendatang diharapkan agar identifikasi risiko dilakukan pada semua unit kerja, sehingga risiko yang ada dapat segera dimitigasi dan dilakukan perbaikan segera.

\section{REFERENSI}

Mamduh M. Hanafi. 2012. Manajemen Risiko. UPP STIM YKPN: Yogyakarta

Mukhlis, M., \& Supriyadi, S. (2018). Desain Sistem Manajemen Risiko Pada Perguruan Tinggi Negeri Badan Hukum (PTN BH). Journal of Applied Accounting and Taxation, 3(2), 158167.

Saunders, M., Lewis, P,. \& Thornhill, A. (2012). Research Methods for Business Students-6 $6^{\text {th }}$ edition. Essex: Pearson Education Limited.

Sekaran, U. (2011). Research Methods for Business. Edisi 1 dan 2. Jakarta: Salemba Empat.

Septiawan, C., \& Sujana, E. (2020, December). Model Sistem Manajemen Risiko Pada Perguruan Tinggi Kesehatan Swasta Di Indonesia (Studi Kasus Di Stikes Indonesia Maju). In Proceeding Seminar Nasional STMA Trisakti. (Vol. 5, No. 1, pp. 63-80).

Stoneburner G, Goguen A, Feringa A. 2001. Risk Management Guide for Information Technology

ISO 31000 Tahun 2018

Wati, Lela Nurlaela. 2018 Manajemen Risiko. STIE Muhammadiyah Jakarta Press: Jakarta

Website: https://www.stiemj.ac.id

https://www.coso.org/Documents/ERM-Understanding-and-Communicating-Risk-Appetite 